\title{
Effects of Business Knowledge on Competences of Business English Teachers in Local Universities and Colleges —— Taking Yunnan Province as an Example
}

\author{
${ }^{1}$ Peng Li, ${ }^{2}$ Yuehui Wu \\ ${ }^{1}$ School of Foreign Languages, Kunming University, Kunming, Yunnan, \\ 650214, China \\ ${ }^{2}$ School of Tourism, Kunming University, Kunming, Yunnan, 650214 , \\ China
}

\begin{abstract}
Higher level of requests have been put on business English (BE) teachers who are playing critical roles in the process of cultivating talents of $\mathrm{BE}$ as wide range of establishment of the major of $\mathrm{BE}$ around China. This paper has investigated the situation of BE teachers' mastering business knowledge based on the universities and colleges in Yunnan province, and further analysed the effects of business knowledge on competences of class teaching, practical instruction and researching. As a result, this paper also proposed some practical solutions from the perspective of teachers themselves and which has offered references for the future studies.

Keywords: business English; business knowledge; local universities and colleges; business English teacher
\end{abstract}

\section{Introduction}

The aim of the Business English Program is to cultivate advanced applicationoriented, business-oriented, business-oriented, and business-oriented foreign language skills, which can be used in the specific economic, social and economic sectors. Colleges and universities according to their own situation and strive to 
maximize the use of existing resources to achieve optimal teaching results, which can train qualified business English professionals. In many resources, teachers are undoubtedly the most critical, should the teacher does not have a good teacher and can do their best to use and the personnel training are out of the question. More and more scholars have begun to pay attention to this problem and have done some research to analyze the current status of teachers of business English teachers, and to propose solutions to existing problems.

\section{Research on the status quo of business English teachers and defects}

Through the collation of many documents, the current study of business English teacher teachers focuses on several aspects: (1) the composition of teachers. The other is non-English professional background of teachers, such as economics, management, law and so on. The conclusion is that these two kinds of teachers have their own strengths, but do not meet the business English teacher's complex ability requirements. (2) the average level of teachers and academic qualifications is low. In addition to a few key institutions, other local colleges and universities are generally at a low level of teachers, teaching assistants and lecturers accounted for the vast majority. (3) lack of scientific research capacity.

One of the common results of these studies is that most business English teachers are now the traditional English language and literature and English education to professional transition, the lack of knowledge of business knowledge, resulting in its interpretation in the classroom and other related aspects of the ability to limit. In addition to a small number of scholars on the status of business English teachers conducted empirical studies, there is no empirical study of business knowledge in business English teacher capacity building in-depth investigation and analysis, it cannot be made Targeted measures to solve the problem.

\section{The study design}

\subsection{The purpose of the study}

This paper aims to investigate the ability of business English teachers' business knowledge in local colleges by means of questionnaires, and analyze the impact of business knowledge on classroom teaching ability, practical guidance ability and scientific research ability of business English teachers, and put forward practical and feasible measures.

\subsection{The study object}

The survey was conducted mainly in Kunming, Yunnan University of Finance and Economics, Yunnan Forestry University, Yunnan University, Yunnan 
Normal University, Qujing Normal University and so on, which have already set up Business English major (direction) in Yunnan. . The number of questionnaires is 50 , and the recovery rate is $58 \%$.According to the questionnaires, the questionnaires are collected, the effective rate was $100 \%$.

\subsection{The research methods and content}

Based on the existing questionnaire, according to the author's professional management and teaching practice to guide the experience, the scale has been adjusted, supplemented, deleted, and then the study of the quantitative analysis method, Used for data collection and collation. (1) the situation of classroom teaching ability of teachers; (2) the ability of teachers to guide the practice; (3) the capacity of teachers in scientific research (4) the ability of teachers to master the business knowledge; (5) the situation of teachers' needs and the professional development of teachers. The main problem is the use of multiple choice questions and Likert five scales, namely: 1 = very agree, 2 = agree, 3 = general, 4 $=$ do not agree, $5=$ very disagree. Accordingly, if the average is closer to 1 , the teacher's acceptance is higher; if the average is closer to 5, the teacher's acceptance is lower.

\subsection{The hypothesis model}

This research mainly testifies the influence of the mastery of business English teachers' knowledge of business English to their classroom teaching ability, practical guidance ability and scientific research ability. The hypothesis is as follows:

Hypothesis 1: The higher the ability of business English teachers to master business knowledge, the stronger their classroom teaching ability.

Hypothesis 2: Business English teachers in local universities have higher ability to master business knowledge, and their practical guidance ability is stronger.

Hypothesis 3: The higher the ability of business English teachers to master business knowledge, the stronger their scientific research ability.

\section{The analysis results}

In this study, the data were analyzed with IBM SPSS21.0. The main results are as follows:

\subsection{The basic situation of teachers}

\begin{tabular}{llccl}
\hline Project & \multicolumn{4}{c}{ Percentage of classification } \\
\hline Gender & male: $31.03 \% ;$ & Female: $68.97 \%$ \\
\hline \multirow{2}{*}{ Age } & $26-30: 6.9 \% ;$ & $31-35: 37.93 \% ;$ & $36-40: 34.48 \% ;$ \\
& $41-45: 6.9 \% ;$ & $46-50: 10.34 \% ;$ & $51-55: 3.45 \%$ \\
\hline
\end{tabular}




\begin{tabular}{|c|c|c|c|}
\hline Education & Bachelor: $6.9 \%$; & master: $82.76 \%$; & Ph.D.: $10.34 \%$ \\
\hline Job Title & $\begin{array}{ll}\text { Assistant: } & 6.9 \% ; \\
\text { Associate } & \text { Professor : } \\
31.03 \% ; & \\
\end{array}$ & $\begin{array}{l}\text { Lecturer: } \quad 58.62 \% \\
\text { Professor: } 3.45 \%\end{array}$ & \\
\hline $\begin{array}{l}\text { Professional } \\
\text { background } \\
(1-3)\end{array}$ & $\begin{array}{l}\text { English literature: } 79.31 \% \\
\text { English Teaching: } 24.14 \% \\
\text { Management: } 13.79 \% \\
\text { Politics and history: } 6.9 \%\end{array}$ & & $\begin{array}{l}\text { Business English : } \\
37.93 \% \\
\text { Translation: } 20.69 \% \\
\text { Economy and Trade: } \\
3.45 \% \\
\text { Others: } 6.9 \% \\
\end{array}$ \\
\hline $\begin{array}{l}\text { Whether has } \\
\text { the industry } \\
\text { experience }\end{array}$ & Yes: $62.07 \%$ & No: $37.93 \%$ & \\
\hline $\begin{array}{l}\text { Whether has } \\
\text { the domestic } \\
\text { learning } \\
\text { experience }\end{array}$ & Yes: $68.97 \%$ & No: $31.03 \%$ & \\
\hline $\begin{array}{l}\text { Whether } \\
\text { study abroad }\end{array}$ & Yes: $44.83 \%$ & No: $55.17 \%$ & \\
\hline $\begin{array}{l}\text { Obtain a } \\
\text { professional } \\
\text { qualification } \\
\text { certificate in } \\
\text { addition to } \\
\text { English and } \\
\text { teacher } \\
\text { qualifications }\end{array}$ & Yes: $41.38 \%$ & No: $58.62 \%$ & \\
\hline
\end{tabular}

From the above data can be seen: (1) teachers are still 31-40 years of age mainly young and middle-aged. This part of the teachers have a certain number of years of teaching experience, easy to accept new teaching ideas and methods, generally have the ability to use modern electronic equipment and network technology; (2) Master degree, has a certain research capacity, (3) title to lecturer-based, this part of the majority of teachers at the same time is a master, urgently in both the title and academic qualifications have a breakthrough. It is gratifying that the proportion of associate professors living in the second, indicating that in recent years in the declaration and construction of business English subjects, colleges and universities in Yunnan Province began to realize the importance of title structure and made adjustments, senior title teachers can promote teaching and research (4) professional background is still the traditional "English Language and Literature" major, but we can see that many teachers have been in other areas of expertise have been the development of professional development of teachers, (5) industry experience than expected increase, indicating that the current construction of applied undergraduate colleges in the trend, the colleges and universities have realized the importance of schoolenterprise cooperation, and increase the (6) Compared with the domestic learning experience, teachers generally lack of foreign learning experience. As a foreign language teacher, there should be a certain period of foreign life and learning 
experience, close contact with foreign culture, especially the business environment, so as to effectively improve their teaching effectiveness and practical guidance; (7) In addition to teacher certification and English-related certificates. Most teachers do not have other relevant professional qualification certificates. Obtaining vocational qualification certificate, not only conducive to their own ability to improve, but also conducive to effectively guide students, thus cultivating a real application-oriented undergraduate talent.

\subsection{The basic situation of the variables}

It is not difficult to see that teachers are generally lack of knowledge of their business, especially in a specific area, such as "I know a certain business areas, such as accounting, legal, trade, etc. $(\mathrm{m}=3.28)(\mathrm{M}=3.14)$ "," I am familiar with the foreign trade business process and can fill in the relevant documents $(\mathrm{m}=$ 3.24) "," I am familiar with the basic knowledge of business operations, such as the establishment, management, Financing, etc. $(\mathrm{m}=3.17)$ ". Teachers have a low level of understanding of the economic development of the country and the region.

Because of some teaching experience, the majority of teachers on such issues higher degree of recognition, but also can be found, involving the use of business knowledge teaching capacity recognition is still low, such as: "I have skill theory with practice, students $(\mathrm{M}=2.69)$ "," I am able to properly integrate the relevant knowledge of economics, management and law $(\mathrm{m}=2.69)$ ".

Teachers are generally low in self-assessment of this part, such as: "I am able to guide the business English professional (direction) graduate graduation practice." ( $\mathrm{M}=2.79)$ "," I can guide students to participate in business English $(\mathrm{M}=2.76)$ ", indicating that the current business English teachers on the students' internship and the degree of understanding of the paper and the guiding ability is still relatively lacking.

Business English as a new discipline, its research areas there is a large gap. Although there are well-known scholar in the subject orientation and development of a prospective study [15] - [17], but also try to young teachers pointing to the future direction of research and feasibility, but the perennial frontline teachers in teaching Most of them belong to the literature review class, lack of creativity and depth, but also very difficult to compete with other disciplines to get the project on the same topic, the satisfaction of teachers is also the time to do so down to the depth of field research, $(\mathrm{M}=2.72)$ "," I often declare the subject of linguistics, pedagogy and other related areas of research and project $(\mathrm{m}=3.28)$ ", I am familiar with the cutting-edge business English disciplines related research.

Whether there is industry experience "and" Obtaining professional qualification certificates other than English and Teacher's Qualifications "in the controllable variables and it can further verify its ability to master the impact of business knowledge. 


\subsection{The impact of business knowledge on teachers' competencies}

Most of the teachers' professional background is English language and literature and English education, and graduated from college directly into the university to teach, and as teachers have little opportunity to enter the industry line practice. Even some of the teachers have some experience (including part-time), but also mainly related to daily business activities, and professional areas, such as accounting, legal, trade and foreign trade processes and other industry experience is very lacking. These areas of professional practitioners need years of professional training and practice, rather than English teachers across the professional short-term able to do the job. How to make students have a more forward-looking vision? The current business English (direction) of the training program has a practical module to guide the lack of business knowledge of teachers led to the practice of students is low, which cannot be well adapted to the employment and further study, resulting in business English students bottlenecks, which is Urgent need to pay attention to the problem.

\section{The solution method}

\subsection{The teacher's own demands}

Through further investigation, we find that the local business English teachers themselves are aware of the negative impact of the lack of business knowledge and are eager to change this situation, summarized as follows: (1) the most urgent need for business English teachers the quality (44.83\%) and related industry experience (41.38\%); (2) Business English teachers have the most important teaching skills $(68.97 \%)$ to integrate relevant subject knowledge; (3) Business English teachers should first emphasize their own business knowledge (48.28\%) and business experience (34.48\%); (4) If you have the opportunity to visit famous universities at home and abroad, the most urgent study is business knowledge $(48.28 \%)$ and business practice (34.48\%) (6) Most teachers think it is necessary to organize regular business English teacher teaching seminars (86.21\%). (5) Most teachers think it is necessary to get the relevant professional qualification certificate $(65.52 \%)$;

\subsection{The specific measures}

I still advocate the English teachers themselves continue to seek ways to improve, of course, if we can use a better macroeconomic environment and policy support is even better. Measures to start from the micro, with operability, so as to effectively improve the local business English teachers of business knowledge to master the ability.

Teachers should seek a variety of ways to study business knowledge. For example, through self-learning, query-related information, the use of now convenient, rich and diverse network resources, such as the MBA think tank 
network (website: http://www.mbalib.com/), can query some technical terms, Wikipedia (Http://www.wikipedia.org/), which provides a comprehensive view of some of the knowledge points, and often reads business magazines such as Harvard Business Review (Harvard Business Review), Economics People "(The Economist), etc., can learn a lot of authentic business English expression, and a profound understanding of economic phenomena. Business English teachers should also share their own learning channels and lessons learned, especially those with business background, should be more responsible for the team to help, so that everyone's comprehensive ability has improved.

Within the school should strengthen horizontal cooperation, by the school coordination of resources, make full use of local application-oriented colleges and universities for the majority of the advantages of integrated institutions, so faculty in the allocation of teachers and professional cooperation can complement each other. On the one hand, foreign language college (the majority of domestic business English major is opened by the Foreign Language Institute) can be hired to manage the faculties of the teachers to business English students to class, business English teachers attend classroom, which is more direct Learning, and understanding of teachers are better than students, to learn by analogy, knowledge points will be faster and more profound grasp, if there are difficult problems, but also to these business professionals to ask teachers to explore and deepen the knowledge of the Understanding; on the other hand, may also send foreign language teachers to the Department of Economics and Management courses. It should be noted that, before the lecture should be related to the relevant departments and teachers to communicate and coordinate, the teachers themselves have to comply with the lecture system, as students as themselves, not to be late to not quit absenteeism, and do a preview and review, Perseverance, if you can listen to such a lesson seriously, the knowledge of this area will have a more profound understanding of the future in classroom teaching and practice guidance, the knowledge will not float on the surface and even a little knowledge, Language too. Interdisciplinary reporting should be encouraged, as well as interdisciplinary course teaching, the Department of Management by the teachers for business English teachers to do the relevant lectures and training. Make full use of resources within the school to enhance the business English teachers the ability to master business knowledge.

Business English teachers in local universities should actively pay attention to and participate in business English training and training, including professional academic conferences. Local business English teachers are generally young, and the majority of master's degree can be bold in the professional interdisciplinary Ph.D., select the management of professional, and institutions are not limited to domestic and English-speaking countries. The bottleneck of the improvement of the qualifications of many business English teachers in local colleges and universities lies in their geographical limitations and professional unity, but these can be breakthrough. Local colleges and universities are orientated as "localoriented" and "service-oriented". They can make use of their regional characteristics. For example, universities in Yunnan and Southeast Asian countries have more international exchanges than English and American 
countries. Business English teachers have their own advantages in English language, while improving education, but also closely integrated with the needs of the development of the region, the country's social and economic life of the situation, so in the future classroom teaching, practical guidance and research to play Regional advantages, but also make their own business knowledge and ability to get a qualitative improvement.

\section{Conclusion}

This study also has many shortcomings, such as the number of survey samples is too small, mainly using quantitative research. Future research can be combined with regional development, more empirical research, because the situation of economic and social development in different regions are different, whether using qualitative research methods or quantitative research methods, if you can start from a specific problem, combined with the region's development real facts to start research, this is the key to effectively solve the problem.

\section{Acknowledgements}

Kunming Institute 2015 application-oriented personnel training reform and innovation project ---- "The market demand-oriented application business English professional curriculum construction".

\section{References}

[1] Song Xiaosi. Research on the Cultivation of Business English Teachers' Quality in Universities, Border Economy and Culture, 55(12), pp.68-70, 2010

[2] Guo Guihang, Xu Dan. Research on the Cultivation of the Ability of Business English Teachers in Colleges and Universities - from the Perspective of Internationalization and Localization. Modern Education Science, 8 (5), pp.8791, 2013

[3] Yuan Qingrong. A Study on Strengthening the Construction of Business English Teachers. Journal of Changchun University of Science and Technology, 12(10), pp. 18- 20, 2012

[4] Li Danqian. A Study on the Construction of Business English Undergraduate Major Teachers in Business Colleges, Journal of Heilongjiang College of Education, 9(6), pp.58- 61, 2011

[5] Lu Wenyi. The Present Situation and the Path of Business English Teachers' Professional Development. Journal of Zhengzhou Institute of Aeronautical Industry Management, 8(4), pp.85-87, 2014 